\title{
PATHOLOGICAL STUDIES ON ADVERSE EFFECTS OF THE ENVIRONMENTAL TOXICANT BISPHENOL A ON THE MALE RABBITS AND THE PROTECTIVE ROLE OF VITAMIN C
}

\author{
AZAB, A.M.S.; ASSI, M.M.A. and RAWASH, Z.M. \\ Department of Reproductive Pathology and Artificial Insemination and Embryo Transfer Dept., Animal Reproduction \\ Research Institute, Agricultural Research Center
}

Received: 20 May 2016; $\quad$ Accepted: 21 June 2016

\begin{abstract}
This study was carried out on 15 mature male New Zealand rabbits divided into three groups (five rabbits / group). Group I, kept as control and daily intubated with control vehicle (olive oil). Group II, daily intubated with bisphenol A (dissolved in olive oil) at a dose level of $100 \mathrm{mg} / \mathrm{kg}$ body weight (minimal toxic dose). Group III, daily intubated with bisphenol A (dissolved in olive oil) at a dose level of $100 \mathrm{mg} / \mathrm{kg}$ body weight and ascorbic acid (Vitamin C) (dissolved in distilled water) at a dose level of $20 \mathrm{mg} / \mathrm{kg}$ body weight for 56 days (8 weeks) equivalent to one spermatogenic cycle in rabbits. One rabbit was sacrificed every two weeks from three groups (i.e. $2,4 \& 6$ weeks), while two rabbits were sacrificed in the $8^{\text {th }}$ week to get blood and histopathological samples. Semen analysis applied weekly for each male rabbit. Histopathological examination revealed that, the testes and epididymis showed mild to severe degrees of degeneration by increasing days of experiment. Moreover, congestion and oedema of interstitial tissues of testis and hyperplasia of lining epithelium of epididymal tubules were noticed. These histopathological changes were ameliorated in the rabbits treated with bisphenol A plus vitamin C group. Other parenchymatous organs as kidneys, liver and lungs showed mild degeneration in intoxicated group and ameliorated in the rabbits treated with bisphenol A plus vitamin $\mathrm{C}$. Concerned semen analysis, there was significant decrease in the sperm count, live / dead ratio and percentage of individual sperm motility. On the other hand, there was significant increase in the total sperm abnormalities in the bisphenol A treated group rather than the other two groups. Testosterone hormone levels were 7.96 \pm 0.12 , $1.72 \pm 0.13$ and $7.19 \pm 0.47 \mathrm{ng} / \mathrm{ml}$ in control, bisphenol A and bisphenol A plus vitamin C groups, respectively. Statistically, there was a significant $(\mathrm{P}<0.05)$ reduction in testosterone concentration in the bisphenol A treated group compared with the bisphenol A plus vitamin $\mathrm{C}$ and highly reduction $(\mathrm{P}<0.01)$ compared with the control group.
\end{abstract}

Key words: Pathological studies, Bisphenol, Male rabbits, Vitamin C

\section{INTRODUCTION}

Bisphenol A (BPA) is used as a monomer to manufacture polycarbonate plastic, the resin that lines most food and beverage cares, dental sealants and as an additive in other plastics and it consider one of the highest volume chemicals produced worldwide (Richter et al., 2007 and Calafat et al., 2008). Falconer et al. (2006) stated that plasticizers including bisphenol A (4,4'-isopropylidenediphenol) has become ubiquitous in the environment within the past 80 years because of its presence in a multitude of products, including polycarbonate plastics used in the manufacture of baby formula bottles, water bottles, and other clear plastic containers. Vandenberg (2007) also reported that BPA is also used in the epoxy resin that lines the inside of metal

Corresponding author: Dr. AZAB, A.M.S

E-mail address: ahmedazab42@yahoo.com

Present address: Dept. of Reproductive Pathology and Artificial Insemination and Embryo Transfer Dept., Animal Reproduction Research Institute, Agricultural Research Center food and soda cans, medical devices, and credit card receipts.

BPA is consumed when it leaches from plastic containers into foods or drinks when they are heated or when they become broken or cracked. Other potential routes of exposure to BPA include air, dust, water, 5-gallon water coolers, printer inks, toners and thermal receipt paper (used by most gas stations and supermarkets), where BPA can rub off paper onto our hands and into our mouths. Li et al. (2009a) studied the exposure to BPA in the workplace was associated with adult male sexual dysfunction as erectile dysfunction, reduced sexual desire, ejaculation difficulties and overall dissatisfaction with their sex life than workers with no heightened BPA exposure.

Li et al. (2009b) noticed that the diameter of seminiferous tubules was significantly reduced or no lumen compared with controls, germ cells were malarranged, and there were a few elongated spermatids and many karyopyknotic cells. Leydig cells in the 
interstitial tissue were decreased in number compared with those of the control group.

There are numerous experimental studies upon laboratory animals which showed that BPA can affect the development of gonads, accessory glands and spermatogenesis. Toyama et al. (2004) studied the effect of BPA on testes of adult mice and rats with electron and light microscopy and observed the abnormalities in spermatids (acrosomal vesicles, acrosomal caps, acrosomes and nuclei of the spermatids were severely deformed). Vom Saal et al. (2007) concluded that in animal studies, BPA has been associated with reproductive abnormalities, hormonal changes and pre-cancerous changes in the breast and prostate.

BPA has been demonstrated in vivo and in vitro experiments to act as an endocrine disrupting chemical (Welshon et al., 2006). Okada and Kai (2008) have presented a significant decrease of mature spermatids number in seminiferous tubules in 4 weeks mouse offspring after $5 \mu \mathrm{g}$ BPA administration. Nanjappa et al. (2012) reported that the testicular Leydig cells are the predominant source of the male sex steroid hormone testosterone, which supports the male phenotype and described the effects of developmental exposure of male rats to BPA. Williams et al. (2013) recorded that the California mice territorial marking behavior was reduced and presumed low dominance in the wild could have reproductive consequences for male. This study also suggests that exposure to BPA may lead to lower mate guarding and, as a consequence, increase their risk of infidelity, an atypical outcome for a monogamous species.

Manfo et al. (2014) studied the adverse effects of BPA on male rats and recorded atrophy of the testes and epididymis and alteration of adult sperm parameters (e.g. sperm count, motility and density). Rahimi et al. (2015) reported that the renal injury is one of the side effects of BPA exposure in rats by intra peritoneal injection and resulted in increase concentration of urea and creatinine. Histologically, dilation and hypercellularity of glomeruli and degeneration of epithelium of proximal tubules were found. Karnam et al. (2015) reported that reproductive study in the BPA treated rats with either 50,200 and $600 \mu \mathrm{g} / \mathrm{kg}$ body weight on day 28 revealed that there was significant reduction in the epididymal sperm count, significant decrease in sperm motility percentage, dead count percentage, head and tail abnormality percentage were found to be significantly increased in rats of BPA treated groups as compared to rats of control groups. Histopathologically, testes showed necrosis of germinal layer and spermatogonial cells in the seminiferous tubules.

Morgan (2014) stated that male albino rats treated orally; 3 times weekly for 50 days with $25 \mathrm{mg}$
BPA/kg body weight /day showed testicular hyperemia, testicular degeneration and cellular debris in the lumen. Moreover, there were histopathological changes in liver, kidneys and brain. Paal et al. (2014) mentioned the average motility and sperm concentration of male rabbits as $55.55 \pm 26.63 \%$ and $0.55 \pm 0.16 \times 10^{9} \mathrm{ml}$, respectively. The normal value of plasma testosterone in the male New Zealand rabbit was $7.17 \pm 0.72 \mathrm{ng} / \mathrm{ml}$ (Sanni et al., 2012).

The present study was performed to elucidate the protective role of vitamin $\mathrm{C}$ on testicular or reproductive toxicity and histopathological alterations induced by bisphenol A.

\section{MATERIALS AND METHODS}

\section{Animals:}

The present study was carried out on 15 mature male New Zealand White rabbit (6 months old, weighed about $2 \mathrm{~kg}$ ) purchased from farm of the ministry of agriculture. All rabbits were housed in individual wire cages and received a balanced ration diet for two weeks before the start of the experiment.

\section{Bisphenol A and Vitamin C:}

The chemical structure of bisphenol A or hydroxylated diphenylalkanes consists of two phenolic rings joined together through a bridging carbon $\left(\mathrm{CH}_{3}\right)_{2} \mathrm{C}\left(\mathrm{C}_{6} \mathrm{H}_{4} \mathrm{OH}\right)_{2}$ (Perez et al., 1998 and Erickson, 2008). Bisphenol A was obtained from Sigma Aldrich Co. (CAS Number 80-05-7). Vitamin C (L-ascorbic acid) was purchased from ElGomhoria Company for Chemical Products.

\section{Experimental design:}

Animals (15 mature male rabbits) were classified into 3 groups. Group I: Five rabbits which were daily intubated with control vehicle (olive oil). Group II: Five rabbits which were daily intubated with bisphenol A (dissolved in olive oil) at a dose level of $100 \mathrm{mg} / \mathrm{kg}$ body weight (minimal toxic dose) according to Sadek et al. (2014). Group III: Five rabbits which were daily intubated with bisphenol A (dissolved in olive oil) at a dose level of $100 \mathrm{mg} / \mathrm{kg}$ body weight and ascorbic acid (Vitamin C) (dissolved in distilled water) at a dose level of 20 $\mathrm{mg} / \mathrm{kg}$ body weight according to Lebas (2000). Up to 8 weeks the whole length of spermatogenic cycle in rabbit. One rabbit was sacrificed each two weeks from three groups (i.e. $2,4 \& 6$ weeks), while the other two rabbits of each group were sacrificed at the $8^{\text {th }}$ week to get blood for hormonal profile and histopathological samples. Semen analysis applied weekly for each male rabbit.

\section{Pathological examination:}

Postmortem examination of sacrificed animals was carried out and gross findings for each organ were recorded. Tissue specimens from testes and epididymis were fixed in formol saline solution $(10 \%$ formalin in $0.9 \% \mathrm{NaCl}$ ) then routinely processed in 
an automated tissue processor, embedded in paraffin, sectioned at 3-5 $\mu \mathrm{m}$, and stained with haematoxylin and eosin stain (Bancroft and Gamble, 2008), then examined by light microscopy.

\section{Semen collection and evaluation:}

Semen was collected every week using a teaser and an artificial vagina. The semen samples were assessed immediately after collection for individual motility, sperm abnormality, live dead ratio and sperm cell concentration according to Boiti et al. (2005).

1- Sperm individual motility using a light microscope at X100 magnification after dilution of the semen with $2.9 \%$ sodium citrate dihydrate solution according to Woston and Martin (1972).

2- Assessment of abnormal sperms using fast green stain according to Wells and Awa (1970).

3- Live dead ratio of spermatozoa using eosinnigrosin staining technique according to BjoÈrndahl et al. (2003).

4- Sperm concentration using the improved Neubauer hemocytometer slide after staining with eosin according to Smith and Mayer (1955).

\section{Testosterone hormone profile:}

Blood samples were taken from the jugular vein of rabbit bucks at the day of necropsy and kept at room temperature for complete clotting and centrifuged at $3000 \mathrm{rpm}$ for the separation of serum and stored at $20^{\circ} \mathrm{C}$. Testesterone levels were assayed with ELISA technique using a commercial kit (Byk, Dietzenbach, Germany) in private lab (Olayemi, 2007).

\section{Statistical analysis:}

The obtained data of testosterone hormone and semen pictures was analyzed using Costat Computer Program (1986) Cottort Software.

\section{RESULTS}

\section{Histopathological examination:}

Mild testicular changes were noticed during the $2^{\text {nd }}$ week consisting of thickening of basement membranes of seminiferous tubules with vacuolar degenerative changes in the lining spermatogenic cells in few seminiferous tubules and oedema in the interstitial tissues which appeared homogenous and faintly oesinophilic. In addition, degenerated spermatids and residual bodies in the lumen of some seminiferous tubules were prominent (Fig. 1).

Meanwhile on the $4^{\text {th }}$ week, moderate degeneration was seen in some of the seminiferous tubules in the form of moderate thickening of basement membranes and hypospermatogenesis. Interstitial tissues showed congestion and oedema. Moreover, increased number of the degenerated spermatids and residual bodies in the lumen of the seminiferous tubules were also noticed (Figs. 2\& 3).
Concerning the lesions observed during the $6^{\text {th }}$ week, the testicular lesions were more pronounced. Moderate thickening of the basement membranes of seminiferous tubules and depletion of spermatogenesis were observed in the most of seminiferous tubules. In addition, the tubules showed increased number of the degenerated spermatids and residual bodies in their lumen. Perivascular oedema in the interstitial tissues was also noticed (Fig. 4).

During the $8^{\text {th }}$ week of treatment, the testicular lesions turned to be severe giving the picture of testicular atrophy, the seminiferous tubules showed severe degeneration in most of seminiferous tubules and exhibited complete absence of the spermatogenesis with the presence of only one layer spermatogenic and sertoli cells (Fig. 5).

Mild vacuolar degeneration of the epididymal ductal epithelium and interstitial oedema were seen at $2^{\text {nd }}$ week. These alterations gradually aggrevated till the end of experiment which appeared more pronounced and clear. Moreover, hyperplasia of the lining epithelial cells of the tubules was seen more than one columnar cell layers which detected at the $6^{\text {th }}$ and $8^{\text {th }}$ weeks (Fig. $7 \& 8$ )

In the third group (treated with BPA and vitamin C) the testicular and epididymal lesions observed in the treated group (second group) were ameliorated gradually starting from $2^{\text {nd }}$ week till the end of the experiment where the testicular structure appeared nearly normal (Fig. 6\& 9).

\section{II- Semen evaluation:}

The following parameters of the semen analysis were statistically analyzed to compare the data of each parameter of the intoxicated group to the control value, bisphenol A plus Vit $\mathrm{C}$ through the spermatogenic cycle (8 weeks).

Upon the comparison of the bisphenol A group to the other two groups (control and bisphenol A plus vitamin C) there was significant decrease in the sperm count per milliliter, individual sperm motility and live dead ratio. While, there was significant increase in the total sperm abnormalities in the bisphenol A treated group rather than the other two groups (Tab. 1).

In the first and second weeks post intoxication data presented in table (1) and showed significant $(\mathrm{P}<0.05)$ reduction in the progressive motility in the bisphenol A treated group $(63 \pm 2.99 \%)$ compared with the control and bisphenol A plus vitamin $\mathrm{C}$ groups $(75 \pm 1.66 \%$ and $73.5 \pm 1.83 \%$, respectively). Similarly, there was no significant difference among the control and bisphenol A plus vitamin $\mathrm{C}$ groups regarding the sperm cell concentration, while there was a significant difference $(\mathrm{P}<0.05)$ with the bisphenol A treated group $\left(119.5 \times 10^{6} \pm 10.46\right.$ sperm cell $/ \mathrm{ml})$. Also, no significant difference among the 
control and bisphenol A plus vitamin C groups regarding the live dead ratio, while there was a significant difference $(\mathrm{P}<0.05)$ with the bisphenol A treated group $(76.7 \pm 2.02 \%)$. Data also indicated that control and bisphenol A plus vitamin $\mathrm{C}$ groups reduced significantly $(\mathrm{P}<0.05)$ sperm abnormalities $(14.6 \pm 1.59 \%$ and $16.3 \pm 1.23 \%$, respectively) compared with bisphenol A treated group $(28.6 \pm 2.49 \%)$.

In the third and fourth weeks post intoxication data presented in table (1) and showed significant $(\mathrm{P}<0.05)$ reduction in the progressive motility in the bisphenol A treated group (58.75 $\pm 2.95 \%)$ compared with the control and bisphenol A plus vitamin C groups $(79.375 \pm 2.39 \%$ and $81.87 \pm 2.30 \%$, respectively). Similarly, there was no significant difference among the control and bisphenol A plus vitamin $\mathrm{C}$ groups regarding the sperm cell concentration, while there was a significant difference $(\mathrm{P}<0.05)$ with the bisphenol A treated group $\left(88.38 \times 10^{6} \pm 2.30\right.$ sperm cell $\left./ \mathrm{ml}\right)$. Also, no significant difference among the control and bisphenol A plus vitamin $\mathrm{C}$ groups regarding the live dead ratio, while there was a significant difference $(\mathrm{P}<0.05)$ with the bisphenol A treated group $(63.75 \pm 4.14 \%)$. Data also indicated that control and bisphenol A plus vitamin $\mathrm{C}$ groups reduced significantly $\quad(\mathrm{P}<0.05) \quad$ sperm abnormalities $(12.38 \pm 1.28 \%$ and $15.5 \pm 1.38 \%$, respectively) compared with bisphenol A treated group $(40.13 \pm 1.69 \%)$.

In the fifth and sixth weeks post intoxication data presented in table (1) and showed significant $(\mathrm{P}<0.05)$ reduction in the progressive motility in the bisphenol A treated group $(53.33 \pm 3.33 \%)$ compared with the control and bisphenol A plus vitamin $\mathrm{C}$ groups $(77.5 \pm 1.71 \%$ and $75.83 \pm 2.71 \%$, respectively).
Similarly, there was no significant difference among the control and bisphenol A plus vitamin $\mathrm{C}$ groups regarding the sperm cell concentration, while there was a significant difference $(\mathrm{P}<0.05)$ with the bisphenol A treated group $\left(78.67 \times 10^{6} \pm 0.03\right.$ sperm cell $/ \mathrm{ml}$ ). Also, no significant difference among the control and bisphenol A plus vitamin $\mathrm{C}$ groups regarding the live dead ratio, while there was a significant difference $(\mathrm{P}<0.05)$ with the bisphenol $\mathrm{A}$ treated group $(60.16 \pm 3.06 \%)$. Data also indicated that control and bisphenol A plus vitamin $\mathrm{C}$ groups reduced significantly $(\mathrm{P}<0.05)$ sperm abnormalities $(10.17 \pm 1.62 \%$ and $12.83 \pm 1.42 \%$, respectively) compared with bisphenol A treated group $(44.67 \pm 2.14 \%)$.

In the seventh and eighth weeks post intoxication data presented in table (1) and showed significant $(\mathrm{P}<0.05)$ reduction in the progressive motility in the bisphenol A treated group $(50 \pm 4.08 \%)$ compared with the control and bisphenol A plus vitamin $\mathrm{C}$ groups $(80 \pm 2.04 \%$ and $77.5 \pm 3.22 \%$, respectively). Similarly, there was no significant difference among the control and bisphenol A plus vitamin $\mathrm{C}$ groups regarding the sperm cell concentration, while there was a significant difference $(\mathrm{P}<0.05)$ with the bisphenol A treated group $\left(54 \times 10^{6} \pm 4.24\right.$ sperm cell $/ \mathrm{ml}$ ). Also, no significant difference among the control and bisphenol A plus vitamin $\mathrm{C}$ groups regarding the live dead ratio, while there was a significant difference $(\mathrm{P}<0.05)$ with the bisphenol A treated group $(48.5 \pm 4.55 \%)$. Data also indicated that control and bisphenol A plus vitamin $\mathrm{C}$ groups reduced significantly $(\mathrm{P}<0.05)$ sperm abnormalities $(11 \pm 1.08 \%$ and $12.75 \pm 2.01 \%$, respectively) compared with bisphenol A treated group $(46.75 \pm 3.01 \%)$.

Table 1: Semen picture in spermatogenic cycle (1: 8 weeks) post intoxication.

\begin{tabular}{ccccc}
\hline Treatments & Motility & Live Dead Ratio & Abnormalities & Concentration \\
\hline Control (1\&2 weeks) (5 rabbits) & $75 \pm 1.66^{\mathrm{a}}$ & $92.4 \pm 0.62^{\mathrm{a}}$ & $14.6 \pm 1.59^{\mathrm{a}}$ & $211 \times 10^{6} \pm 19.06^{\mathrm{a}}$ \\
\hline Bisphenol A group (1\&2 weeks) (5 rabbits) & $63 \pm 2.99^{\mathrm{b}}$ & $76.7 \pm 2.02^{\mathrm{c}}$ & $28.6 \pm 2.49^{\mathrm{b}}$ & $119.5 \times 10^{6} \pm 10.46^{\mathrm{c}}$ \\
\hline $\begin{array}{c}\text { Bisphenol A \& Vit C group (1\&2 weeks) } \\
\text { (5 rabbits) }\end{array}$ & $73.5 \pm 1.83^{\mathrm{a}}$ & $85.4 \pm 0.89^{\mathrm{b}}$ & $16.3 \pm 1.23^{\mathrm{a}}$ & $158.3 \times 10^{6} \pm 5.15^{\mathrm{b}}$ \\
\hline $\begin{array}{c}\text { Control (3\&4 weeks) (4 rabbits) } \\
\text { Bisphenol A group (3\&4 weeks) (4 rabbits) }\end{array}$ & $59.375 \pm 2.39^{\mathrm{a}}$ & $92.87 \pm 0.81^{\mathrm{a}}$ & $12.38 \pm 1.28^{\mathrm{a}}$ & $257.63 \times 10^{6} \pm 26.68^{\mathrm{a}}$ \\
\hline $\begin{array}{c}\text { Bisphenol A \& Vit C group (3\&4 weeks) } \\
\text { (4 rabbits) }\end{array}$ & $81.87 \pm 2.30^{\mathrm{a}}$ & $90.13 \pm 1.14^{\mathrm{a}}$ & $15.5 \pm 1.38^{\mathrm{a}}$ & $184.37 \times 10^{6} \pm 8.54^{\mathrm{b}}$ \\
\hline $\begin{array}{c}\text { Control (5\&6 weeks) (3 rabbits) } \\
\text { Bisphenol A group (5\&6 weeks) (3 rabbits) }\end{array}$ & $53.33 \pm 3.33^{\mathrm{b}}$ & $60.16 \pm 3.06^{\mathrm{c}}$ & $44.67 \pm 2.14^{\mathrm{b}}$ & $78.67 \times 10^{6} \pm 0.03^{\mathrm{b}}$ \\
\hline $\begin{array}{c}\text { Bisphenol A \& Vit C group (5\&6 weeks) } \\
\text { (3 rabbits) }\end{array}$ & $75.83 \pm 2.71^{\mathrm{a}}$ & $88.33 \pm 1.25^{\mathrm{a}}$ & $12.83 \pm 1.42^{\mathrm{a}}$ & $213.67 \times 10^{6} \pm 11.21^{\mathrm{a}}$ \\
\hline Control (7\&8 weeks) (2 rabbits) & $80 \pm 2.04^{\mathrm{a}}$ & $88.75 \pm 1.31^{\mathrm{a}}$ & $11 \pm 1.08^{\mathrm{a}}$ & $237 \times 10^{6} \pm 24.25^{\mathrm{a}}$ \\
\hline Bisphenol A group (7\&8 weeks) (2 rabbits) & $50 \pm 4.08^{\mathrm{b}}$ & $48.5 \pm 4.55^{\mathrm{b}}$ & $46.75 \pm 3.01^{\mathrm{b}}$ & $54 \times 10^{6} \pm 4.24^{\mathrm{b}}$ \\
\hline $\begin{array}{c}\text { Bisphenol A \& Vit C group (7\&8 weeks) } \\
\text { (2 rabbits) }\end{array}$ & $77.5 \pm 3.22^{\mathrm{a}}$ & $90.75 \pm 2.83^{\mathrm{a}}$ & $12.75 \pm 2.01^{\mathrm{a}}$ & $228.25 \times 10^{6} \pm 24.38^{\mathrm{a}}$ \\
\hline
\end{tabular}

Values with different superscripts in the same column are significantly different at $(\mathrm{P}<0.05)$. 


\section{III- Blood sera testosterone hormone profile:}

There was a significant $(\mathrm{P}<0.05)$ reduction in testosterone concentration in the bisphenol A treated group $(1.72 \pm 0.13 \mathrm{ng} / \mathrm{ml})$ compared with the bisphenol A plus vitamin C $(7.19 \pm 0.47 \mathrm{ng} / \mathrm{ml})$ and highly reduction $(\mathrm{P}<0.01)$ compared with the control group $(7.96 . \pm 0.12 \mathrm{ng} / \mathrm{ml})$.

Table 2: Sera testosterone concentration of the treated groups 56 days post intoxication ( 5 rabbits for each group).

\begin{tabular}{cccc}
\hline Parameters & Control & Bisphenol A & BPA \& Vit C \\
\hline Testosterone & ${\mathbf{7 . 9 6} \pm 0.12^{\mathrm{a}}}^{\mathrm{a}}$ & ${\mathbf{1 . 7 2} \pm 0.13^{\mathrm{b}}}^{\mathrm{b}}$ & ${\mathbf{7 . 1 9} \pm 0.47^{\mathrm{a}}}$ \\
\hline
\end{tabular}

Values with different superscripts in the same column are significantly different at $(\mathrm{P}<0.05)$.

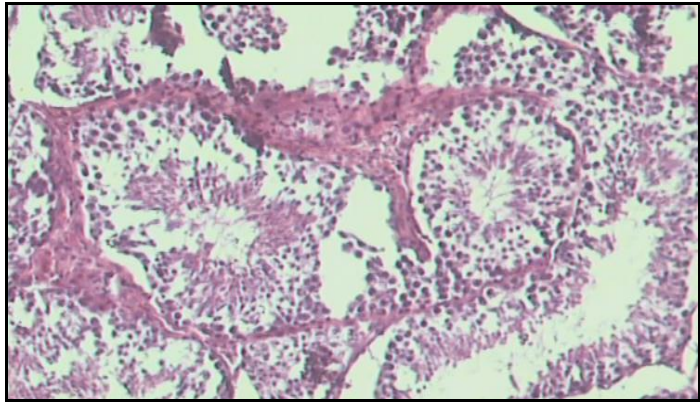

Fig. 1: Rabbit buck testis of BPA intoxicated group sacrificed at two weeks showing mild degeneration with thickened basement membranes of seminiferous tubules and hypospermatogenesis (H\&E, X100).

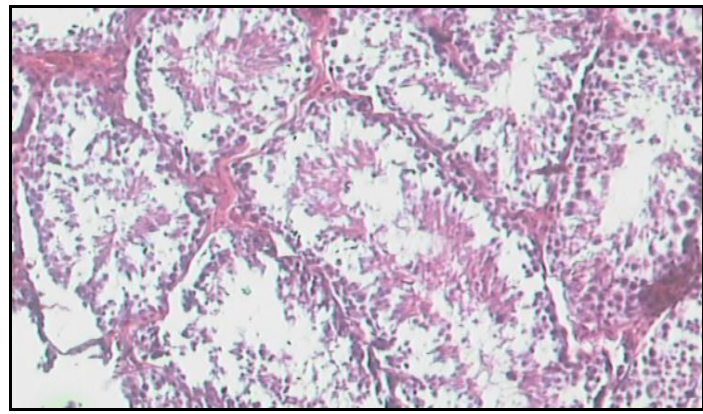

Fig. 3: Rabbit buck testis of BPA intoxicated group sacrificed at six weeks showing moderate degeneration with thickened basement membranes of seminiferous tubules and hypospermatogenesis (H\&E, X100)

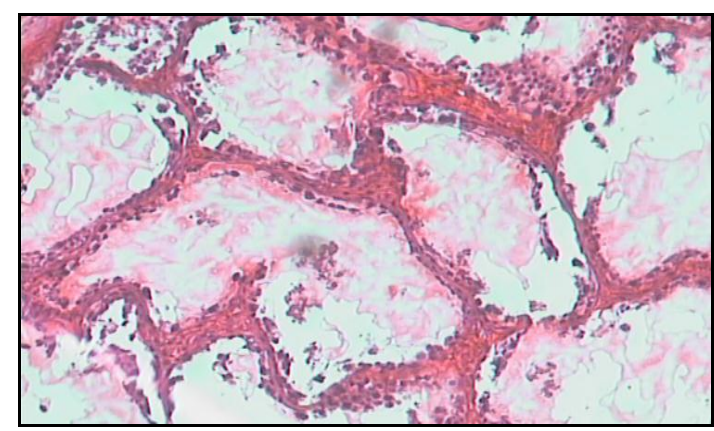

Fig. 5: Rabbit buck testis of BPA intoxicated group sacrificed at eight weeks post intoxication showing severe degeneration with thickened basement membranes of seminiferous tubules and aspermatogenesis (H\&E, $\mathrm{X} 100$ ).

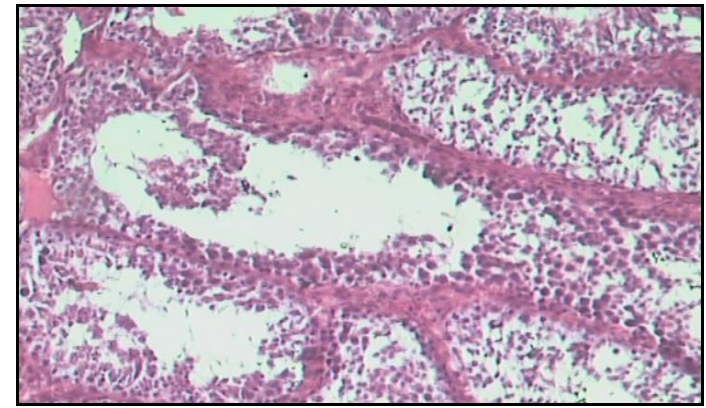

Fig. 2: Rabbit buck testis of BPA intoxicated group sacrificed at four weeks showing moderate degeneration with thickened basement membranes of seminiferous tubules and hypospermatogenesis (H\&E; X100).

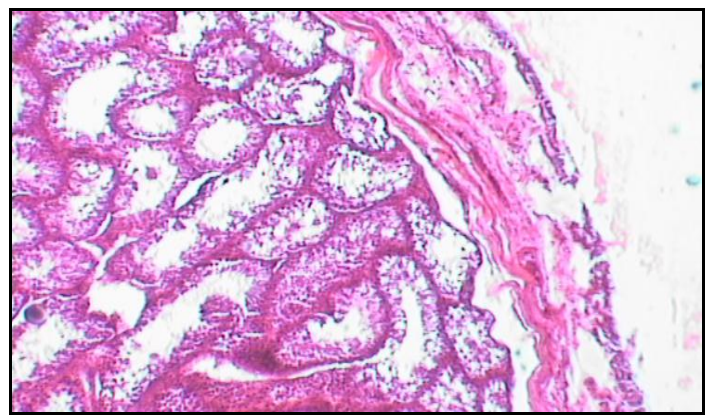

Fig. 4: Rabbit buck testis of BPA intoxicated group sacrificed at eight weeks post intoxication showing severe degeneration with thickened basement membranes of seminiferous tubules and hypospermatogenesis (H\&E, X40).

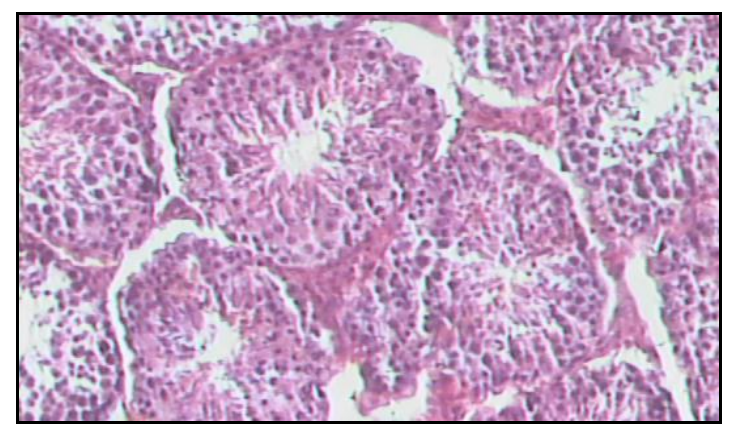

Fig. 6: Rabbit buck testis of BPA plus vitamin C group showing more or less the normal appearance of seminiferous tubules and interstitial tissues $(\mathrm{H} \& \mathrm{E}$, $\mathrm{X} 100$ ). 


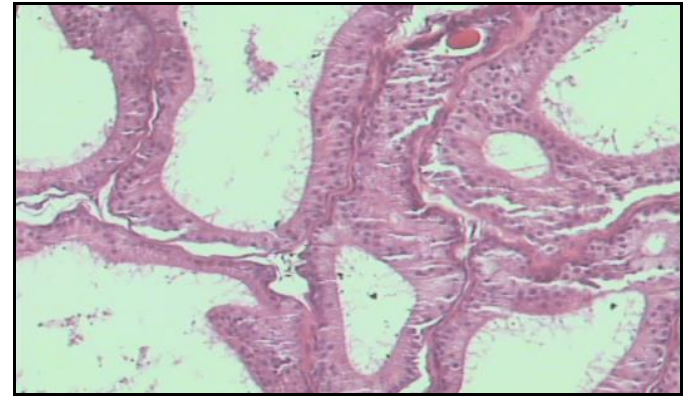

Fig. 7: Rabbit buck epididymis of BPA intoxicated group sacrificed at two weeks showing mild vacuolar degenerated tubules with few sperms in lumen (H\&E, X100).

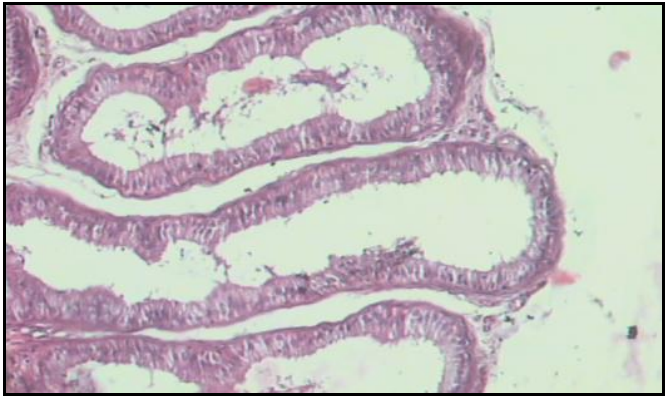

Fig. 8: Rabbit buck epididymis of BPA intoxicated group sacrificed at four weeks showing moderate vacuolar degenerated tubules with cellular debris and few sperms in lumen and epithelial cells hyperplasia in many tubules (H\&E, X100)

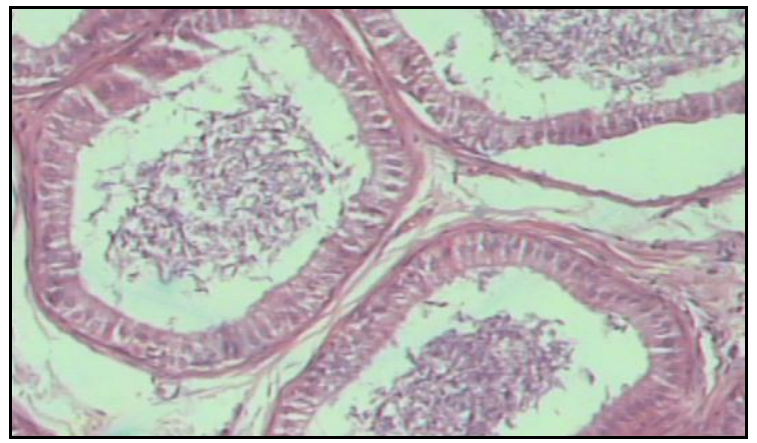

Fig. 9: Rabbit buck epididymis of BPA plus vitamin $\mathrm{C}$ group showing more or less the normal appearance of tubules and sperms in lumen $(\mathrm{H} \& \mathrm{E}$, X100).

\section{DISCUSSION}

Exposure to several chemicals and environmental contaminants has been reported to increase oxidative stress in body by disturbing the prooxidant/ antioxidant balance of cells (Ho et al., 1998 and Aydogan et al., 2008). BPA was previously reported to induce oxidative damage in several tissues (Aydogan et al., 2010 and Korkmaz et al., 2010 and 2011). It is widely accepted that antioxidants may delay or inhibit the oxidation of lipids or other molecules by inhibiting the initiation, or propagation of oxidizing chain reactions (Velioglu et al., 1998 and Aitken and Roman, 2008). These involve absorption and neutralization of free radicals, quenching singlet and triplet oxygen, and decomposing peroxides (Osawa, 1994). Considerable attention has recently been focused on some nutritional factors such as polyphenols that could counteract oxidative damages and therefore be beneficial through their antioxidant properties (RiceEvans et al., 1997 and Luczaj et al., 2009). Also, Chitra et al. (2003b) reported that bisphenol A induced oxidative stress in epididymis and caused degeneration of the epididymal epithelium of rats. In consistent with our histopathological findings, the testis and epididymis showed degeneration, congestion, atrophy, and germinal cell debris that come in contact with Aydogan et al. (2010) of rats administrated BPA. Chitra et al. (2003b) mentioned that degeneration of epididymal epithelium with reduction in the number of sperms was observed at all doses of bisphenol A treated rats. BPA has been shown to be decomposed to many kinds of metabolites including BPA radical by a reaction with radical oxygen (Sajiki, 2001). Several evidences indicated that BPA exerts a potent oxidant activity in various tissues via reactive oxygen species (ROS) production which results in inhibition of antioxidant enzymes; increased $\mathrm{H}_{2} \mathrm{O}_{2}$ and lipid peroxidation products as recorded by (Bindhumol, 2003; Chitra et al., 2003a\&b; Kabuto, 2003; Obata and Kubota, 2000 and Kourouma et al., 2015). Moreover, polyphenols act as reactive oxygen and nitrogen species scavengers, redoxactive transition metal chelators and enzyme modulators as recorded by (Rice-Evans et al., 1997; Jian, 2010; El Tohamy and 
El Nattat, 2010 and Saleh et al., 2015). Coadministration with vitamin $\mathrm{C}$ had a protective effect against the bisphenol $\mathrm{A}$ induced toxicity in epididymal sperm and epididymis that come in agreement with our study. The present study confirmed the previously recorded antioxidant effect of vitamin $\mathrm{C}$ that was indicated by increased antioxidant enzymes activities.

Semen evaluation of this study among the whole spermatogenic cycle reach similar to the results by Paal et al. (2014) in the average motility and sperm concentration of male rabbits as $55.55 \pm 26.63 \%$ and $0.55 \pm 0.16 \times 10^{9} \mathrm{ml}$, respectively. Co-administration with vitamin $\mathrm{C}$ reversed the effect of bisphenol $\mathrm{A}$ induced reduction in semen motility, live dead ratio and concentration with increase of sperm abnormalities so vitamin $\mathrm{C}$ considered as antidote for bisphenol A toxicity (Chitra et al., 2003b).

Testosterone level in the present study showed reduction in bisphenol $\mathrm{A}$ intoxicated group in comparison with control and bisphenol A plus vitamin $\mathrm{C}$ groups and that get in accordance of results of (Gunnarsson et al., 2003 and Sanni et al., 2012). It was an expected event because the corresponding cytotoxic effect of bisphenol A on Leydig cells responsible for reduction of testosterone production.

Vandenberg et al. (2007) and Li et al. (2009b) found that BPA may disrupt spermatogenesis by impacting various testicular cell types and given that human exposure to BPA is continuous and BPA can bioaccumulation in some conditions, there still is concern about human reproductive health especially for occupational workers exposed to higher levels of BPA.

\section{CONCLUSION}

the results of this study revealed that oral BPA administration induced adverse oxidative stresses on the exposed animals as evidenced by the recorded abnormalities and histopathological alterations in the genital organs. Co-treatment with vitamin $\mathrm{C}$ provided a protective antioxidant role against such adverse effects. So, it is recommended to use vitamin $\mathrm{C}$ as a protector for all living organisms intensively exposed to BPA especially in occupational settings.

\section{REFERENCES}

Aitken, R.J. and Roman, S.D. (2008): Antioxidant systems and oxidative stress in the testes. Oxidative Medicine and Cellular Longevity, 1,$1 ; 15: 24$

Aydogan, M.; Korkmaz, A.; Barlas, N. and Kolankaya, D. (2008): The effect of vitamin $\mathrm{C}$ on bisphenol A, nonylphenol and octylphenol induced brain damages of male rats. Toxicology, 249; 35: 39.

Aydogan, M.; Korkmaz, A.; Barlas, N. and Kolankaya, D. (2010): Pro-oxidant effect of vitamin $\mathrm{C}$ coadministration with bisphenol $\mathrm{A}$, nonylphenol, and octylphenol on the reproductive tract of male rats. Drug Chem. Toxicol., 33, 2; 193: 203.

Bancroft, J.D. and Gamble, M. (2008): Theory and Practice of Histological Techniques. 7th Ed, Churchill Livingstone London, UK, and pp: 125-138 \&328-329.

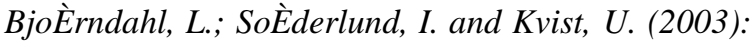
Evaluation of the one-step eosin-nigrosin staining technique for human sperm vitality assessment. Human Reproduction, 18, 4; 813: 816.

Bindhumol, V.; Chitra, K.C. and Mathur, P.P. (2003): Bisphenol A induces reactive oxygen species generation in the liver of male rats. Toxicology, 188, 117: 124.

Boiti, C.; Castellini, C.; Theau-Clement, M.; Besenfelder, U.; Liguori, L.; Renieri, T. and Pizzi, F. (2005): Guidelines for the handling of rabbit bucks and semen. World Rabbit Sci. 2005, 13; 71: 91.

Calafat, A.M.; Ye, X.; Wong, L.Y.; Reidy, J.A. and Needham, L.L. (2008): "Exposure of the U.S. Population to Bisphenol A and 4-tertiaryoctylphenol: 2003-2004," Environ. Health Perspectives, vol. 116, 1; 39: 44.

Chitra, K.C.; Latchoumycandane, C. and Mathur, P.P. (2003a): Induction of oxidative stress by bisphenol A in the epididymal sperm of rats. Toxicology, 185, 1-2; 119: 127.

Chitra, K.C.; Rao, K.R. and Mathur, P.P. (2003b): Effect of bisphenol A and co-administration of bisphenol $\mathrm{A}$ and vitamin $\mathrm{C}$ on epididymis of adult rats: a histological and biochemical study. Asian J. Androl, 5, 3; 203: 208

Costat Computer Program Copyright (1986): Version 3.03 copyright Cottort Software.

El Tohamy, M.M. and El Nattat, W.S. (2010): Effect of Antioxidant on Lead-Induced Oxidative Damage and Reproductive Dysfunction in Male Rabbits. Journal of American Science, 6, 11; 613: 622 .

Erickson, B.E. (2008): "Bisphenol A under scrutiny". Chemical and Engineering News. American Chemical Society, 86, 22; 36: 39.

Falconer, I.R.; Chapman, H.F.; Moore, M.R. and Ranmuthugala, G. (2006): Endocrinedisrupting compounds: a review of their challenge tosustainable and safe water supply and water reuse. EnvironmentalToxicology, vol. $21 ; 181: 191$.

Gunnarsson, D.; Nordberg, G.; Imdgress, P. and Selstam, G. (2003): Hazards of heavy metal contamination. Br. Med. Bull., 68; 167: 182.

Ho, Y.S.; Magnenat, J.L.; Gargano, M. and Cao, J. (1998): The nature of antioxidant defense 
mechanisms: a lesson from transgenic studies, Environ. Health Perspect., 106, 5; 1219: 1228.

Jian, M.L.; Peter, H.L.; Qizhi, Y. and Changyi, C. (2010): Chemical and molecular mechanisms of antioxidants: experimental approaches and model systems. J Cell Mol Med., 14, 4; 840:860.

Kabuto, H.; Hasuike, S.; Minagawa, N. and Shishibori, T. (2003): Effects of bisphenol A on the metabolisms of active oxygen species in mouse tissues. Environ. Res., 93, 1; 31:35.

Karnam, S.S.; Ghosh, R.C; Mondal, S. and Mondal, $M$. (2015): Evaluation of subacute bisphenolA toxicity on male reproductive system. Veterinary World, 8, 6; 738: 745

Korkmaz, A.; Aydogan, M.; Kolankaya, D. and Barlas, N. (2010): Influence of vitamin C on bisphenol A, nonylphenol and octylphenol induced oxidative damages in liver of male rats. Food Chem. Toxicol., 48, 10; 2865: 2871.

Korkmaz, A.; Aydogan, M.; Kolankaya, D. and Barlas, N. (2011): Vitamin C coadministration augments bisphenol A, nonylphenol, and octylphenol induced oxidative damage on kidney of rats, Environ. Toxicol., 26, 4; 325: 337.

Kourouma, A.; Quan, C.; Duan, P.; Qi, S.; Yu, T.; Wang, Y. and Yang, K. (2015): Bisphenol A Induces Apoptosis in Liver Cells through Induction of ROS. Reasearch Article. Advances in Toxicology, Hindawi Publishing Corporation; 10 pages.

Lebas, F. (2000): Vitamins in Rabbit Nutrition: Literature Review and Recommendation. World Rabbit Science, 8, 4; 185: 192.

Li, D.; Zhou, Z.; Qing, D.; He, Y.; Wu, T.; Miao, M.; Wang, J.; Weng, X.; Ferber, J.R.; Herrinton, L.J.; Zhu, Q.; Gao, E.; Checkoway, H. and Yuan, W. (2009a): "Occupational exposure to bisphenol-A (BPA) and the risk of SelfReported Male Sexual Dysfunction". Human Reproduction, 25, 2; 519: 527.

Li, Y.J.; Song, T.B.; Cai, Y.Y.; Zhou, J.S.; Song, X.; Zhao, X. and Wu, X.L. (2009b). Bisphenol A Exposure Induces Apoptosis and Upregulation of Fas/Fasl and Caspase-3 Expression in The Testes Of Mice. Toxicol. Sci., 108, 2; 427: 436.

Luczaj, W.; Zapora, E.; Szczepanski, M.; Wnuczko, K. and Skrzydlewska, E. (2009): Polyphenols action against oxidative stress formation in endothelial cells. Acta. Pol. Pharm., 66, 6; 617: 624.

Manfo, F.P.; Jubendradass, R.; Nantia, E.A.; Moundipa, P.F. and Mathur, P.P. (2014): Adverse effects of bisphenol A on male reproductive function. Environ Contam Toxicol, 228; 57: 82.

Morgan, A.M.; El-Ballal, S.S.; El-Bialy, B.E. and EL-Borai, N.B. (2014): Studies on the potential protective effect of cinnamon against bisphenol A- and octylphenol-induced oxidative stress in male albino rats. Toxicology Reports, 1; 92: 101.

Nanjappa, M.K.; Simon, L. and Akingbemi, B.T. (2012): The Industrial Chemical Bisphenol A (BPA) Interferes with Proliferative Activity and Development of Steroidogenic Capacity in Rat Leydig Cells. Biology of Reproduction, 86, 5,$135 ; 1: 12$.

Obata, T. and Kubota, S. (2000): Formation of hydroxyl radicals by environmental estrogenlike chemicals in rat striatum. Neurosci. Lett., 296, 1; 41: 44.

Okada, A. and Kai, O. (2008): Effect of estradiol-17 $\beta$ and bisphenol A administred chronically to micetrought pregnancy and lactation on the male pup's reproductive system. Asian Journ. of Andrology, 30, 4; 271: 276.

Olayemi, F.O. (2007): Evaluation of the reproductive and toxic effects of Cnestis ferruginea de Candolle) root extract in male rats. Ph.D Thesis. Dept. of Physiology, University of Ibadan, 26: 263.

Osawa, T. (1994): Novel natural antioxidants for utilization in food and biological systems, in: I. Uritani, V.V. Garcia, E.M. Mendoza (Eds.), Postharvest Biochemistry of Plant FoodMaterials in the Tropics, Japan Scientific Societies Press, Tokyo, Japan, pp. 241: 251.

Paal, D.; Krockova, J.; Ondruska, L.; Slanina, T.; Strejcek, F. and Massanyl, P. (2014): Effect of semen collection frequency on the progress in the motility of rabbit spermatozoa. Slovak J. Anim. Sci., 47, 2; 61: 67.

Perez, P.; Pulgar, R.; Olea-Serrano, F.; Villalobos, M; Rivas, A.; Metzler, M.; Pedraza, V. and Olea, N. (1998): The estrogenicity of bisphenol A-related diphenylalkanes with various substituents at the central carbon and the hydroxy groups. Environ. Health Perspectives, 106, 3; 167: 174.

Rahimi, O.; Farokhi, F.; Khojasteh, S.M.B. and Ozi, S.A. (2015): The effect of Bisphenol A on serum parameters and morphology of kidney's tissue. Biological Forum International Journal, 7, 2; 79: 90 .

Rice-Evans, C.A.; Miller, N.J. and Papanga, G. (1997): Antioxidant properties of phenolic compounds, Trends Plant Sci., 2, 152: 159.

Richter, C.A.; Birnbaum, L.S.; Farabollim, F.; Newbold, R.R.; Rubin, B.S.; Talness, C.E.; Vanderbergh, J.G.; Walser-Kuntz, D.R. and VomSaal, F.S. (2007): In vitro effects of Bisphenol A in Laboratory rodent studies. Reprod. Toxicol., 24, 2; 199: 224.

Sadek, K.M.; Abouzed, T.K. and Ayoub, M.A. (2014): Oxidative and Hormonal Disruptions Underlie Bisphenol A-Induced Testicular Toxicity in Male Rabbits. International Journal of Biological, Biomolecular, Agricultural, Food 
and Biotechnological Engineering, 8, 11; 1206: 1212.

Saleh, S.S.; Sawiress, F.A.; Tonys, M.A.; Hassanin, A.M.; Khattab, M.A. and Bakeer, M.R. (2015): Protective Role of Some Feed Additives against Dizocelpine Induced Oxidative Stress in Testes of Rabbit Bucks. Journal of Agricultural Science, 7, 10; 239: 252.

Sajiki, J. (2001): Decomposition of bisphenol A by radical oxygen. Environ. Int., 27, 315: 320.

Sanni, A.A.; Arowolo, R.O.A. and Olayemi, F.O. (2012): Preliminary study on the effect of castration and testosterone replacement on testosterone level in the New Zealand male rabbit. African Journal of Biotechnology, 11, 43; 10146-10148.

Smith, J.T. and Mayer, D.T. (1955): Evaluation of sperm concentration by the hemocytometer method comparison of four counting fluids. Fert. Steril., 6; 271: 275.

Toyama, Y.; Maekawa, M.; Ito, C. and Toshimuri, K. (2004): Adverse effects of bisphenol A to spermiogenesis in mice and rats. Archives of Histol. and Citol., 67, 4; 373: 381.

Vandenberg, L.N. (2007): Human exposure to bisphenol A. Reproductive Toxicology, vol. 24, 2; 139: 177.

Velioglu, Y.; Mazza, G.; Gao, L. and Oomah, B. (1998): Antioxidant activity and total phenolics in selected fruits, vegetables, and grain products. J. Agric. Food Chem., 46, 10; 4113: 4117.

Vom Saal, F.S.; Akingbemi, B.T.; Belcher, S.M.; Bimbaum, L.S.; Crain, D.A.; Eriksen, M. and Zoeller, R.T. (2007): "Chapel Hill bisphenol A expert panel consensus statement: integration of mechanisms, effects in animals and potential to impact human health at current levels of exposure". Reproductive Toxicology, vol. 8, 131: 138.

Wells, U. and Awa, O. (1970): New techniques for assessing acrosomal characteristics of spermatozoa. J. Dairy Sci., 53; 227: 232.

Welshons, W.V.; Nagel, S.C. and Vom Saal F.S. (2006): Large effects from small exposures. Endocrine mechanisms mediating effects of bisphenol A at levels of human exposure. Endocrin., 147, 6; 56: 69.

Williams, S.A.; Jasarevic, E.; Vandas, G.M.; Warzak, D.A.; Geary, D.C.; Ellersieck, M.R.; Roberts, R.M. and Rosenfeld, C.S. (2013): Effects of Developmental Bisphenol A exposure on reproductive-related behaviors in California mice (Peromyscus californicus): A Monogamous Animal Model. PLOS Journal, 8, 2; 1371: 1378.

Woston, S. and Martin, R. (1972): A comparison of change in acrosomes of deep frozen ram and bull spermatozoa. J. Reprod. Fert., 28; 99-101

\section{دراسات باثولوجية للتأثير السمى للملوث البيئى بيسفينول ـ أ على ذكور الأرانب والدور الوقائى لفيتامين ج}

\section{أحمد محدد صابر محمود عزب ، محمد محدد /حد عاصى ، زاهر اببراهيم رواش}

Email: ahmedazab42@yahoo.com
Assiut University web-site: www.aun.edu.eg

تمت هذه الدراسة على 10 من ذكور الأر انب النيوزيلاندية الناضجة التي قسمت إلى ثناث مجموعات من خمسة أر انب لكل واحدة.

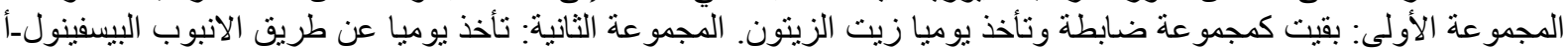

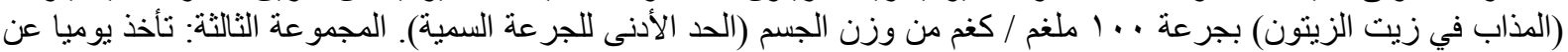

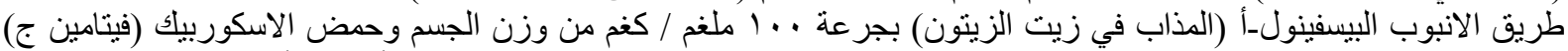

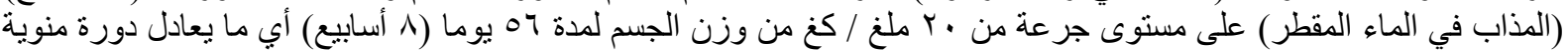

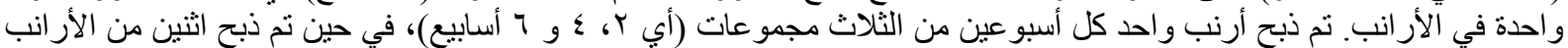

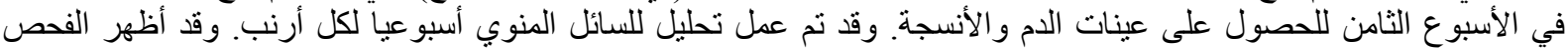

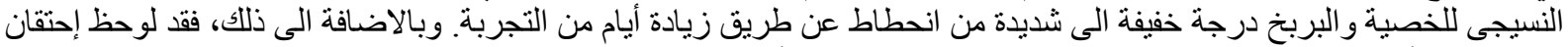

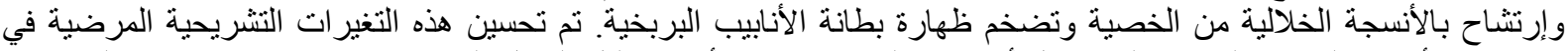

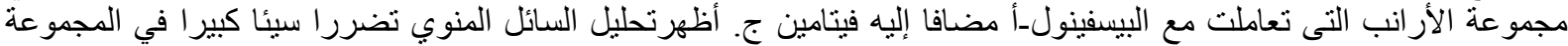

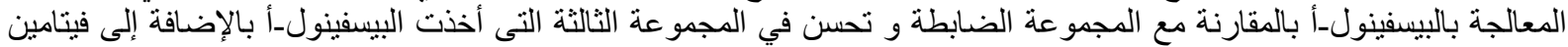

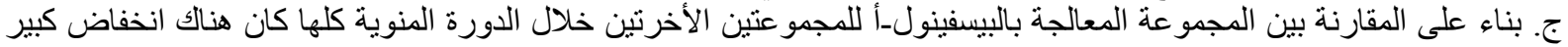

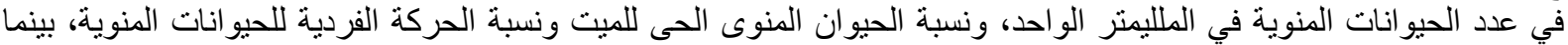

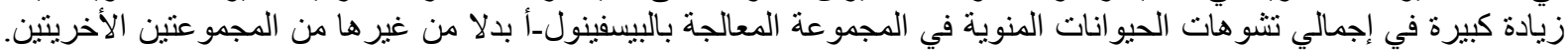

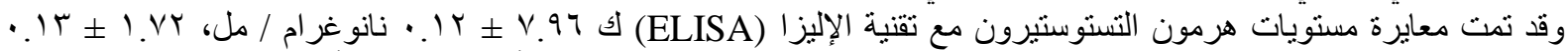

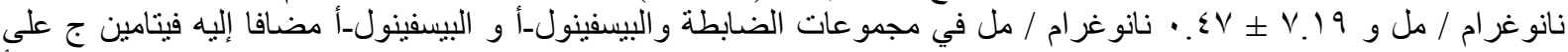

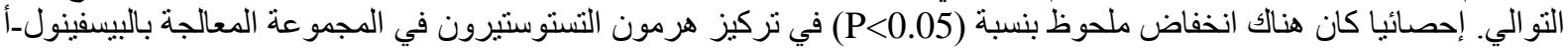

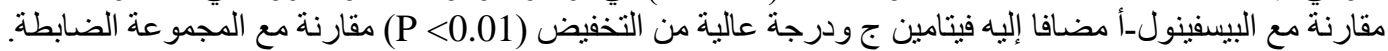

